\title{
Meningkatkan Keterampilan Proses Sains dan Hasil Belajar Materi Pokok Momentum dan Impuls melalui Model Pembelajaran berbasis Masalah bagi Peserta Didik SMAN 2 Mawasangka Tengah
}

\author{
Sariani $^{1)}$, Muhammad Anas ${ }^{2)}$, Luh Sukariasih ${ }^{2)}$ \\ ${ }^{1}$ Alumni Jurusan Pendidikan Fisika FKIP Universitas Halu oleo \\ ${ }^{2}$ Dosen Jurusan Pendidikan Fisika FKIP Universitas Halu Oleo \\ Email: sarianipendfisika@gmail.com
}

\begin{abstract}
This study aims to describe the science process skills, cognitive physics learning outcomes, and completeness of cognitive physics learning outcomes in class X MIA SMAN 2 Middle Mawasangka who are taught using problem-based learning models on the subject matter of momentum and impulses. This type of research is classroom action research that has been carried out in 2 cycles. The subjects in this study were students of class X MIA SMAN 2 Mawasangka Tengah in the academic year 2018/2019 with the number of students 23 people. There are two data analyzed in this research, they are the science process skill data obtained from the observation sheet and the cognitive physics learning outcomes data obtained from the learning achievement test. From the results of data analysis, it was found that the students' process skills using problem-based learning models in each cycle tended to increase from a sufficient category of 1.67 in the first cycle to a good category of 2.87 in the second cycle. The cognitive physics learning outcomes taught by using problem-based learning models obtained value distribution: in the first cycle values obtained from 51 to 98 with an average value of 71.2. In cycle II, values were obtained from 64 to 100 with an average value of 81.0. 3) Learning outcomes of students' cognitive physics in the subject matter of momentum and impulses taught by using problem-based learning models can be increased by the number of students who have completed in cycle I amounted to $60.8 \%$ increased to $78.3 \%$ in cycle II. Based on the results of the study it can be concluded that the learning of physics on the subject matter of momentum and impulses taught using problem-based learning models has increased the science process skills and the cognitive physics learning outcomes.
\end{abstract}

Keywords: Problem-Based Learning Model; Sciences Process Skills; Cognitive Field Learning Outcomes.

Abstrak: Penelitian ini bertujuan untuk mendeskripsikan keterampilan proses sains, hasil belajar fisika ranah kognitif, dan ketuntasan hasil belajar fisika ranah kognitif peserta didik kelas X MIA SMAN 2 Mawasangka Tengah yang diajar menggunakan model pembelajaran berbasis masalah pada materi pokok momentum dan impuls. Jenis penelitian ini adalah penelitian tindakan kelas yang telah dilaksanakan dalam 2 siklus. Subjek dalam penelitian ini adalah peserta didik kelas X MIA SMAN 2 Mawasangka Tengah tahun ajaran 2018/2019 dengan jumlah peserta didik 23 orang. Ada dua data yang dianalisis dalam penelitian ini yaitu data keterampilan proses sains yang diperoleh dari lembar observasi dan data hasil belajar fisika ranah kognitif yang diperoleh dari tes hasil belajar. Dari hasil analisis data diperoleh bahwa keterampilan Proses peserta didik dengan menggunakan model pembelajaran berbasis masalah pada setiap siklus cenderung meningkat dari kategori cukup 1,67 pada siklus I menjadi kategori baik 2,87 pada siklus II. Hasil belajar fisika ranah kognitif yang diajar dengan menggunakan model pembelajaran berbasis masalah yang diperoleh sebaran nilai: pada siklus I diperoleh nilai dari 51 sampai dengan 98 dengan nilai rata-rata 71,2. Pada siklus II diperoleh nilai dari 64 sampai dengan 100 dengan nilai rata-rata 81,0. 3) Hasil belajar fisika ranah kognitif peserta didik pada materi pokok momentum dan impuls yang diajar dengan menggunakan model pembelajaran berbasis masalah dapat ditingkatkan dengan jumlah persentase siswa yang sudah tuntas pada siklus I adalah sebesar 60,8 \% meningkat menjadi 78,3\% pada siklus II. Berdasarkan hasil penelitian dapat disimpulkan bahwa pembelajaran fisika pada materi pokok momentum dan impuls yang diajar menggunakan model pembelajaran berbasis masalah mengalami peningkatan pada keterampilan proses sains dan hasil belajar fisika ranah kognitif".

Kata Kunci: Model Pembelajaran Berbasis Masalah; Keterampilan Proses Sains; Hasil Belajar Ranah Kognitif. 


\section{PENDAHULUAN}

Berdasarkan hasil observasi dan wawancara yang telah dilakukan kepada pihak sekolah, pada tanggal 12 Maret 2019 bahwa pelaksanaan kegiatan pembelajaran fisika di kelas X SMA Negeri 2 Mawasangka Tengah terdapat satu kelas MIA (Matematika dan Ilmu Pengetahuan Alam), dengan jumlah peserta didik 23 orang yang terdiri dari 9 orang laki-laki dan 14 orang perempuan diperoleh bahwa selama ini hanya menggunakan metode ceramah dan pemberian tugas. Karena, pihak sekolah masih menggunakan Kurikulum Tingkat Satuan Pendidikan (KTSP) sehingga hanya beberapa peserta didik yang aktif dalam mengikuti kegiatan belajar.

Berdasarkan keterangan dari guru mata pelajaran fisika kelas X MIA SMA Negeri 2 Mawasangka Tengah, bahwa nilai pelajaran fisika selama ini masih perlu ditingkatkan, karena dapat di lihat dari hasil persentase ketuntasan belajar hanya mencapai 39,39\% dimana nilai rata-rata hasil ulangan harian peserta didik kelas $\mathrm{X}$ tahun 2017/2018 materi pokok momentum dan impuls yaitu 60 yang mana nilai ini belum memenuhi Kriteria Ketuntasan Minimal (KKM) dari sekolah yaitu 70 .

Penyebab permasalahan yang dialami oleh peserta didik adalah guru masih menggunakan metode pembelajaran yang berpusat pada guru sehingga pada saat guru sedang menjelaskan materi pembelajaran, peserta didik membuat kesibukan sendiri, seperti bermain, menggambar serta bercerita dengan teman sebangkunya. Guru menggunakan metode ini karena mereka beranggapan dengan berceramah kemudian peserta didik mencatat apa yang disampaikan guru maka akan meningkatkan hasil belajar peserta didik, tapi peserta didik kadang menjadi bosan untuk memahami materi. Pembelajaran yang dapat dikatakan optimal adalah guru tidak hanya menjelaskan saja tetapi peserta didik yang harus lebih aktif untuk mencari tahu dan peran guru sebagai fasilitator dan motivator, hal tersebut bertujuan agar peserta didik menjadi lebih mandiri/terampil dan aktif dalam proses belajar pada saat pembelajaran berlangsung. Untuk menciptakan pembelajaran yang optimal harus memikirkan pendekatan dan media yang sesuai dengan materi. Tugas utama guru adalah menyelenggarakan kegiatan pembelajaran yang memungkinkan terjadinya interaksi secara optimal antara sesama peserta didik ataupun peserta didik dengan guru atau sebaliknya.

Berdasarkan masalah tersebut peneliti memilih menggunakan model yang dapat menarik peserta didik agar lebih senang dan semangat dalam belajar fisika sehingga diharapkan hasil berjalannya akan baik. Salah satu model mengajar yang membuat peserta didik aktif berpikir adalah model Pembelajaran Berbasis Masalah (PBM). Dalam model ini peserta didik di hadapkan pada persoalan dan di minta untuk memikirkan dan memecahkan persoalan tersebut. Model pembelajaran ini yang menekankan pada usaha untuk memecahkan masalah diharapkan dapat menuntun peserta didik untuk aktif dan mampu menimbulkan pengaruh untuk memunculkan kemampuan proses sains serta berpengaruh pula terhadap hasil belajar kognitifnya.

Pembelajaran berbasis masalah merupakan pembelajaran yang bercirikan masalah nyata sebagai suatu konteks bagi peserta didik untuk berpikir kritis, kreatif dan keterampilan memecahkan masalah, serta untuk memperoleh pengetahuan konsep yang esensi dari materi momentum dan inpuls. Materi momentum dan impuls penerapannya banyak ditemukan dalam kehidupan sehari-hari, namun pada kenyataannya peserta didik masih merasa kesulitan. Menurut guru sendiri, momentum dan impuls merupakan materi yang dianggap cukup sulit untuk dipahami oleh peserta didik karena butuh pemahaman yang mendalam, sehingga dibutuhkan suatu model pembelajaran yang tepat agar materi ini mudah dipahami oleh peserta didik. Hal ini disebebkan karena PBM memerlukan keterampilan guru untuk menjajikan masalah yang bersifat kontekstual. Pada model PBM dirancang masalah-masalah yang menuntut peserta didik mendapatkan pengetahuan penting, membuat mereka mahir dalam memecahkan masalah dan memiliki strategi belajar sendiri serta memiliki cakapan berpasitipasi dalam tim. Proses pembelajarannya menggunakan pendekatan yang sistematik untuk memecahkan masalah atau menghadapi tantangan yang nanti diperlukan 
dalam karier dan kehidupan sehari-hari (Amala, 2012).

Pembelajaran berbasis masalah memiliki kelebihan pada pemecahan masalah yang merupakan teknik yang cukup bagus untuk memahami isi pelajaran, mengembangkan kemampuan peserta didik untuk berpikir kritis dan mengembangkan kemampuan mereka untuk menyesuaikan dengan pengetahuan baru dan mengaplikasikan pengetahuan yang mereka miliki dalam dunia nyata. Tapi model ini juga memiliki kekurangan yaitu ketika peserta didik tidak memiliki minat atau tidak mempunyai kepercayaan bahwa masalah yang dipelajari sulit untuk dipecahkan, maka mereka akan merasa enggan untuk mencoba. Model pembelajaran ini dirasa tepat sebagai model pembelajaran untuk meningkatkan keterampilan proses sains peserta didik karena berawal dari suatu permasalahan Peserta didik akan terdorong untuk mempelajari berbagai pembelajaran sains, dengan menemukan sendiri solusi dari permasalahan yang disuguhkan, peserta didik akan lebih cepat mengerti karena belajar yang baik adalah belajar dengan melakukan sendiri apa yang dipelajari.

Hamdayama (2016) mengemukakan bahwa pembelajaran berbasis masalah dilaksanakan dengan lima langkah (tahap) kegiatan. Adapun tahapan pembelajran atau sintaks pembelajaran berbasis masalah adalah sebagai berikut: memberikan orientasi tentang permasalahan terhadap peserta didik, mengorganisasikan peserta didik untuk belajar, Membimbing penyelidikan individual maupun kelompok, Mengembangkan dan menyajikan hasil karya, dan Menganalisis dan mengevaluasi proses pemecahan masalah.

Berdasarkan hasil dari beberapa penelitian mengenai Pendekatan Keterampilan Proses Sains maupun pembelajaran berbasis masalah (PBM) antara lain menurut Maretnowati (2007) menunjukkan adanya peningkatan hasil belajar fisika pokok materi pemuaian melalui Pendekatan pembelajaran berbasis masalah. Shofa (2008) menunjukkan bahwa pembelajaran fisika dengan pendekatan keterampilan proses pada materi usaha dan energi dapat meningkatkan hasil belajar peserta didik maupun kreativitas peserta didik.

Adapun menurut Warsono dan Haryanto (2012), pembelajaran berbasis masalah adalah model pemmbelajaran yang berlandaskan konstruktivisme dan mengakomodasikan keterlibatan peserta didik dalam belajar serta terlibat dalam pemecahan masalah yang kontekstual. Hal ini menunjukan pembelajaran berbasis masalah selalu melibatkan peserta didik dalam penyelesaian masalah dan masalah yang digunakan adalah masalah nyata yang sering peserta didik temukan bahkan peserta didik alami sendiri dalam kehidupan sehari-hari. Penelitian terdahulu yang telah dilakukan terkait dengan pembelajaran fisika berbasis masalah menemukan bahwa secara eksplisit pembelajaran berbasis masalah mampu meningkatkan keterampilan proses dan hasil belajar kognitif.

Berdasarkan uraian tersebut maka perlu dilakukan sebuah penelitian mengenai Meningkatkan Keterampilan Proses Sains dan Hasil Belajar Fisika Ranah Kognitif Peserta Didik pada Materi Pokok Momentum dan Impuls Melalui Model Pembelajaran Berbasis Masalah (Problem Based Learning) Kelas X MIA SMAN 2 Mawasangka Tengah.

\section{METODE}

Jenis penelitian ini adalah Penelitian Tindakan Kelas (PTK). Penelitian dilaksanakan pada semester genap tahun ajaran 2018/2019 di kelas X MIA SMA Negeri 2 Mawasangka Tengah pada materi pokok Momentum dan Impuls.

\section{Subjek Penelitin}

Subjek penelitian ini adalah peserta didik kelas X MIA SMA Negeri 2 Mawasangka Tengah yang terdaftar pada semester Genap tahun ajaran 2018/2019, dengan rincian sebagai berikut: Tabel 1 Sebaran Subjek Penelitian Menurut Jenis Kelamin

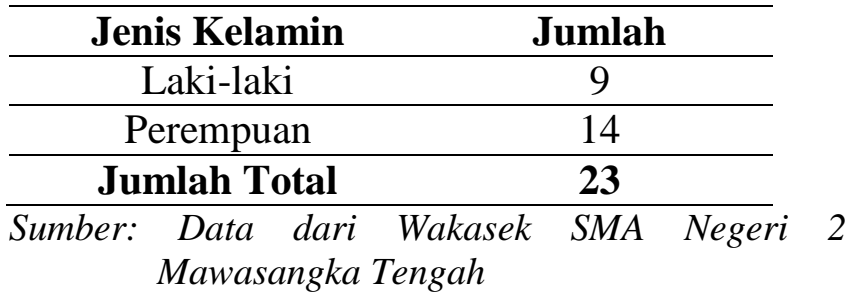


Teknik Pengumpulan Data dan Analisis Data

Dalam Pengumpulan data pada peelitian ini menggunakan 2 macam teknik. Adapun teknik yang digunakan dalam penelitian tindakan kelas adalah observasi dan Tes hasil belajar. Sedangkan teknik analisis data yang digunakan berupa analisis deskriptif yang dimaksudkan untuk memberikan gambaran distribusi keterampilan proses sains dan hasil belajar fisika ranah kognitif yang diajar dengan menggunakan model pembelajaran berbasis masalah.

\section{Indikator Ketuntasan}

Seorang peserta didik dikatakan telah mencapai ketuntasan belajar secara individu apabila peserta didik tersebut telah mendapat nilai $\geq 70$ (Kriteria Ketuntasan Belajar Minimal) di SMA Negeri 2 Mawasangka Tengah). Sebagai indikator keberhasilan dari penelitian tindakan kelas ini adalah jika minimal $75 \%$ jumlah peserta didik yang menjadi subjek penelitian telah memperoleh nilai $\geq 70$ (Kriteria Ketuntasan Belajar Minimal).

\section{Desain Penelitian}

Prosedur penelitian tindakan kelas ini direncanakan terdiri dari 2 (dua) siklus. maka prosedur penelitian tindakan untuk tiap siklus meliputi: 1) permasalahan; 2) penerapan model pembelajaran berbasis masalah; 3) pelaksanaan tindakan (RPP 01) untuk siklus I serta (RPP 02 dan RPP 03) untuk siklus II; 4) observasi dan evaluasi; 5) refleksi. Secara lebih rinci prosedur penelitian tindakan kelas ini dapat dijabarkan sebagai berikut:

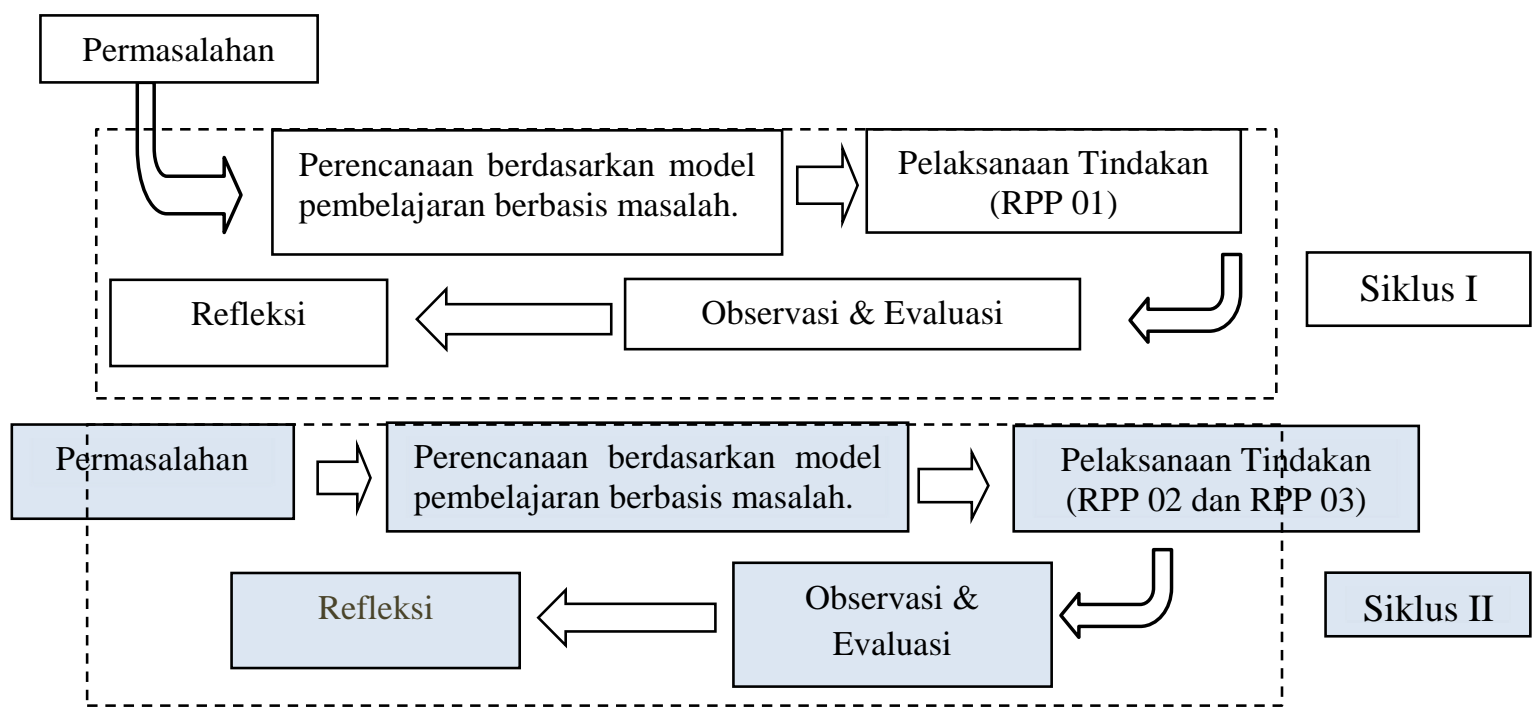

Gambar 1. Rancangan dan desain penelitian tindakan kelas.

Tahap-tahap penelitian tindakan kelas:

\section{Siklus I}

\section{1) Perencanaan}

Kegiatan yang dilakukan selama perencanaan tindakan kelas dengan menerapkan model pembelajaran berbasis masalah pada siklus I yaitu:
a. Merancang pembelajaran RPP tentang Momentum.
b. Membuat Lembar Kerja Peserta Didik (LKPD) tentang Momentum.
c. Membuat lembar pengamatan /observasi keterampilan proses sains peserta didik.

d. Membuat lembar evaluasi hasil belajar ranah kognitif peserta didik pada sub materi pokok Momentum dan Impuls dalam bentuk soal esai dan membuat kunci jawaban yang digunakan dalam penelitian.

\section{2) Pelaksanaan Tindakan}

Kegiatan pada tahap ini adalah melaksanakan kegiatan pembelajaran dengan menerapkan model pembelaran berbasis masalah dalam pembelajaran materi Momentum dan Impuls oleh peneliti sesuai dengan rencana pelaksanaan pembelajaran (RPP) tentang Momentum.

\section{3) Observasi dan Evaluasi}


Dalam tahap ini dilaksanakan observasi terhadap pelaksanaan tindakan dengan menggunakan lembar pengamatan pembelajaran yang telah dirancang sebelumnya. Observasi dilakukan bersamaan dengan kegiatan pembelajaran yang mencakup:

a. Memantau optimalisasi penerapan model pembelajaran berbasis masalah oleh peneliti yang dilakukan oleh observer yaitu guru Fisika.

b. Melihat aktivitas peserta didik selama kegiatan pembelajaran yang dilakukan oleh peneliti.

c. Evaluasi hasil belajar kognitif untuk mengetahui sejauh mana penguasaan peserta didik tentang Momentum dan Impuls dengan menggunakan tes hasil belajar (tes siklus I).

\section{4) Refleksi}

Pada tahap ini peneliti melaksanakan diskusi refleksi berdasarkan hasil yang didapatkan dalam tahap observasi dan evaluasi. Untuk melihat apakah kegiatan yang dilaksanakan telah efektif serta dapat meningkatkan keterampilan proses sains dan hasil belajar kognitif peserta didik pada sub materi pokok Momentum dan Impuls. Dalam tahap ini, keunggulan dan kelemahan-kelemahan yang terjadi dipertahankan dan diperbaiki pada siklus berikutnya. Hasil refleksi digunakan untuk menetapkan langkah-langkah lebih lanjut pada siklus berikutnya.

\section{Siklus II}

Penerapan siklus II untuk mengidentifikasi kekurangan dan kelemahan yang ada pada siklus I. Proses siklus II sama halnya seperti yang ada pada suklus I.

\section{HASIL DAN PEMBAHASAN}

\section{Hasil Analisis Data Keterampilan Proses Sains}

Data keterampilan proses sains peserta didik kelas X MIA SMA Negeri 2 Mawasangka Tengah mataeri pokok Momentum dan Impuls menggunakan model Pembelajaran Berbasis Masalah dapat dilihat pada Tabel berikut:

Tabel 2. Data Skor Nilai Rata-rata Keterampilan Proses Sains Peserta Didik Tiap Pertemuan pada Siklus

\begin{tabular}{|c|c|c|c|c|c|c|c|c|c|c|c|}
\hline \multirow{4}{*}{ No } & \multirow{4}{*}{$\begin{array}{l}\text { Aspek-aspek } \\
\text { yang diamati }\end{array}$} & \multicolumn{10}{|c|}{ Skor Rata-rata Keterampilan Proses Sains Peserta Didik } \\
\hline & & \multicolumn{6}{|c|}{ Siklus I } & \multicolumn{4}{|c|}{ Siklus II } \\
\hline & & \multicolumn{4}{|c|}{ P-1 } & \multirow{2}{*}{$\begin{array}{c}\text { Rata- } \\
\text { rata }\end{array}$} & \multirow{2}{*}{ Kategori } & \multirow{2}{*}{$\mathrm{P}-2$} & \multirow{2}{*}{$\mathrm{P}-3$} & \multirow{2}{*}{$\begin{array}{c}\text { Rata- } \\
\text { rata }\end{array}$} & \multirow{2}{*}{ Kategori } \\
\hline & & I & II & III & IV & & & & & & \\
\hline 1 & $\begin{array}{c}\text { Observasi } \\
\text { (Mengamati) }\end{array}$ & 2 & 2 & 2 & 2 & 2 & Cukup & $\begin{array}{c}2.7 \\
5\end{array}$ & 3 & 2.87 & Baik \\
\hline 2 & $\begin{array}{l}\text { Merumuskan } \\
\text { Masalah }\end{array}$ & 1 & 1 & 2 & 1 & 1.25 & Kurang & $\begin{array}{c}2.5 \\
0\end{array}$ & 3 & 2.75 & Baik \\
\hline 3 & $\begin{array}{l}\text { Melakukan } \\
\text { percobaan }\end{array}$ & 2 & 2 & 2 & 1 & 1.50 & Kurang & 3 & $\begin{array}{c}3.2 \\
5\end{array}$ & 3.12 & Baik \\
\hline 4 & $\begin{array}{l}\text { Menafsirkan } \\
\text { pengamatan }\end{array}$ & 2 & 2 & 1 & 2 & 1.75 & Cukup & $\begin{array}{c}2.7 \\
5\end{array}$ & 3 & 2.87 & Baik \\
\hline 5 & $\begin{array}{c}\text { Menerapkan } \\
\text { Konsep dan } \\
\text { Prinsip }\end{array}$ & 2 & 2 & 2 & 1 & 1.75 & Cukup & $\begin{array}{c}2.5 \\
0\end{array}$ & 3 & 2.75 & Baik \\
\hline 6 & Menyimpulkan & 1 & 2 & 2 & 1 & 1.50 & Kurang & $\begin{array}{c}2.7 \\
5\end{array}$ & $\begin{array}{c}2.7 \\
5\end{array}$ & 2.75 & Baik \\
\hline 7 & $\begin{array}{c}\text { Mengkomunikas } \\
\text { ikan }\end{array}$ & 2 & 2 & 2 & 2 & 2 & Cukup & 3 & 3 & 3 & Baik \\
\hline \multicolumn{2}{|c|}{ Jumlah } & & & & & $\begin{array}{c}11.7 \\
5\end{array}$ & & & & $\begin{array}{c}20.1 \\
2\end{array}$ & \\
\hline Skor & Rata-rata & & & & & 1.68 & Cukup & & & 2.87 & Baik \\
\hline
\end{tabular}

Tabel 2 menunjukkan bahwa distribusi perolehan nilai aspek keterampilan proses sains peserta didik pada setiap pertemuan. Nilai setiap aspek keterampilan proses sains peserta didik 
meningkat dari siklus I ke siklus II. Pada siklus I nilai rata-rata keterampilan proses sains dari seluruh aspek berada pada kategori cukup, sedangkan pada siklus II berada pada kategori baik.

\section{Keterlaksanaan Model Pembelajaran Berbasis Masalah}

Berdasarkan pelaksanaan pembelajaran dengan menggunakan model pembelajaran berbasis masalah pada materi pokok momentum dan impuls diperoleh melalui penilaian guru fisika SMAN 2 Mawasangka Tengah pada aktivitas penelitian dalam mengajar menggunakan lembar observasi aktivitas guru dengan cara memberikan skor pada setiap aspek aktivitas yang dilakukan sesuai dengan kriteria yang telah ditentukan. Skor rata-rata aktivitas guru dapat dilihat pada Tabel 3.

Tabel 3. Data Skor Rata-rata Ketentuan tiap

\begin{tabular}{lcc}
\multicolumn{2}{c}{ Siklus } & \\
\hline & Siklus I & Siklus II \\
\hline Jumlah & 69 & 78 \\
\hline Skor Rata-rata & 3.3 & 3.7 \\
\hline Kategori & Sangat Baik & Sangat Baik \\
\hline
\end{tabular}

Berdasarkan pada Tabel 3 memperlihatkan bahwa skor rata-rata aktivitas guru seluruh aspek yang diperoleh pada siklus I adalah 3,3 dan termasuk kategori sangat baik. Pada siklus II terlihat bahwa aktivitas guru mengalami peningkatan menjadi 3,7 yang termasuk kategori sangat baik. Hal ini berarti kekurangan aspek pada siklus I sudah diperbaiki guru pada siklus II sehingga menunjukkan adanya perubahan perbaikan dalam pembelajaran. Tampak bahwa aktivitas pembelajaran yang dilakukan guru pada siklus II sudah baik dalam hal memberikan motivasi kepada peserta didik dan alokasi waktu. Sehingga guru perlu memperbaiki kekurangan yang dilakukan dan memperkirakan waktu yang digunakan agar sesuai dengan pembelajaran yang direncanakan.

\section{Hasil Belajar Peserta Didik}

Hasil analisis deskriptif terhadap hasil belajar peserta didik pada materi pokok Momentum dan Impuls dengan model pembelajaran berbasis masalah kelas X MIA SMAN 2 Mawasangka Tengah dilihat pada Tabel 4 berikut.

Tabel 4. Data analisis nilai hasil belajar peserta didik

\begin{tabular}{lcc}
\hline & SIKLUS I & SIKLUS II \\
\hline Jumlah & 1638 & 1866 \\
\hline Nilai rata-rata & 71,2 & 81,1 \\
\hline Nilai maksimum & 98 & 100 \\
\hline Nilai minimum & 51 & 64 \\
\hline Jumlah T & 14 & 18 \\
\hline Jumlah BT & 9 & 5 \\
\hline \% Sudah Tuntas & $60,8 \%$ & $78,3 \%$ \\
\hline \% Belum Tuntas & $39.2 \%$ & $21,7 \%$ \\
\hline
\end{tabular}

Tabel 4 memperlihatkan bahwa hasil belajar fisika ranah kognitif peserta didik kelas $X$ MIA SMA Negeri 2 Mawasangka Tengah pada materi pokok Momentum dan Impuls setelah diajar dengan menerapkan model pembelajaran berbasis masalah menunjukkan adanya peningkatan dari siklus I ke siklus II. Pada siklus I penelitian tindakan kelas belum berhasil, sedangkan pada siklus II penelitian tindakan kelas ini dinyatakan berhasil karena telah memenuhi kriteria keberhasilan tindakan.

\section{PEMBAHASAN PENELITIAN}

\section{Keterampilan proses sains}

Hasil analisis deskriptif pada aspek-aspek keterampilan proses sains yang menunjukan bahwa skor rata-rata peserta didik pada siklus I yaitu 1,67 dengan kategori cukup. Rendahnya aspek-aspek tersebut dikarenakan peserta didik belum terbiasa dengan model pembelajaran berbaisis masalah, melakukan kegiatan praktikum secara langsung dan tidak terbiasa mengerjakan LKPD. Selain itu, peserta didik kurang antusias dalam mengikuti proses 
pembelajaran. Solusi yang harus diupayakan yaitu guru lebih berusaha dalam membimbing peserta didik selama proses pembelajaran berlangsung dengan dengan menjelaskan materi secara jelas. Mendekatkan diri kepada peserta didik untuk selalu pertukan informasi dan menanyakan masalah apa yang menjadi kendala mereka. Selain itu, guru harus membuat suasana belajar lebih menyenangkan sehingga peserta didik yang kirang antusias menjadi lebih antusian dalam mengikuti kegiatan pemebelajaran.

Keterampilan proses sains peserta didik pada siklus II mengalami peningkatan dengan memperoleh skor rata-rata yaitu 2,87 yang berada dalam kategori baik seperti pada Tabel 4.2. Ini dilakukan dengan guru memperbaiki aktivitas mengajar terutama pada aspek aktivitas membimbing dan mengarahkan peserta didik melakukan percobaan atau diskusi kelompok serta mengerjakan LKPD. Yang menjadi perhatian guru pada siklus II ini yaitu membimbing dan menjelaskan secara detail pada aspek indikator keterampilan proses sains yang presentasinya masih kurang di siklus I khususnya aspek merumuskan masalah, melakukan percobaan dan menyimpulkan. Selain itu, indikator Keterampilan proses sains lainya juga tidak luput dari perhatian guru. Berdasarkan observasi observer diperoleh gambaran bahwa keterampilan proses sains peserta didik yang di ajar menggunakan model pembelajaran berbasis masalah telah meningkat. Adanya peningkatan pada siklus II menunjukan bahwa peserta didik sudah mulai terbiasa dalam melakukan kegiatan eksperimen dan mengerjakan LKPD dengan model pembelajaran berbasis masalah. Meskipun peninggkatan tidak berbeda jauh dengan nilai rata-rata sebelumnya namun, sudah mencapai nilai dalam kategori baik. Hal ini sejalan menurut Prima (2011) yang menyatakan bahwa pembelajaran berbasis masalah lebih dapat meningkatkan keterampilan proses sains. Penelitian ini juga dilakukan oleh Wahyudi dkk (2015) berpendapat bahwa model pembelajaran berbasis masalah berpengaruh terhadap rata-rata nilai keterampilan proses sains peserta didik.
Model pembelajaran berbasis masalah sangat baik untuk meningkatkan keterampilan proses sains peserta didik karena pembelajaran konvensional kurang mengakomodasi keterampilan proses sains, sejalan dengan pendapat Mayer dkk (2004) bahwa keterampilan proses sains dapat dikuasai peserta didik jika keterampilan berpikir tingkat tinggi didapatkan peserta didik sedangkat keterampilan berpikir tingkat tinggi dapat didapatkan melalui model pembelajaran berbasis masalah.

\section{Hasil belajar peserta didik}

Hasil belajar fisika ranah kognitif peserta didik pada siklus I dengan materi pokok Momentum dan Impuls menunjukkan perolehan nilai rata-rata skor hasil belajar peserta didik sebesar 71,2. Kondisi ini ternyata nilai hasil belajar peserta didik menunjukkan presentase belajar yang diperoleh pada siklus I belum mencapai target. Hal ini disebabkan karena peserta didik belum memiliki kepercayaan diri untuk mengajukan pertanyaan apabila ada hal atau materi yang tidak dimengerti baik sesama teman kelompoknya maupun pada guru. Oleh karena itu guru harus menekankan penguasaan konsep pada materi selanjutnya dan harus memberikan banyak latihan soal terutama jenis soal analisis atau perhitungan. Pada siklus II guru memperhatikan dan melaksanakan langkah-langkah kegiatan pembelajaran yang tidak dilaksanakan pada silus I. pada Tabel 4.4 terlihat bahwa nilai hasil belajar mengalami peningkatan dari 23 orang jumlah peserta didik yang mengikuti tes hasil belajar.

Hasil ketuntasan secara klasikal bahwa nilai rata-rata peserta didik telah mencapai ketuntasan belajar sebesar 81,1. Sehingga dapat dikatakan bahwa peningkatan yang terjadi menunjukan guru telah melakukan perbaikan berdasarkan analisis dan refleksi yang telah dilakukan sebelumnya pada siklus I dan juga tidak terlepas dari peran peserta didik dalam mengikuti pembelajaran secara berkaitan dengan masalah dengan mau bekerjasama bersama anggota kelompoknya.

Peningkatan keterampilan proses sains peserta didik, dan prolehan hasil belajar peserta didik membuktikan bahwa model pembelajaran 
berbasis masalah dapat memberikan pengaruh nilai positif bagi proses pembelajaran, baik dari segi minat maupun hasil belajar peserta didik. Dengan demikian dapat dibuktikan bahwa penerapan model pembelajaran berbasis masalah dapat meningkatkan keterampilan proses sains, dan hasil belajar peserta didik kelas X MIA SMAN 2 Mawasangka tengah pada materi pokok Momentum dan Impuls.

Dengan melihat hasil belajar tersebut menunjukkan bahwa dengan menerapkan model pembelajaran berbasis masalah dapat meningkatkan hasil belajar peserta didik. Peningkatan tersebut sesuai dengan teori yang dijelaskan oleh mulyasa (2006) yang menyatakan bahwa berhasil dan berkualitas apabila seluruhnya tidaknya sebagian besar $75 \%$ peserta didik terlibat secara aktif, baik fisik, mental maupun soaial dalam proses pembelajan. Hasil penelitian menunjukkan adanya peningkatan keaktifan dan hasil belajar peserta didik dapat ditingkatkan dengan rata-rata hasil belajar diperoleh dari hasil tes siklus 1 dan tes siklus 2. Hasil tersebut juga sejalan dengan penelitian yang dilakukan oleh Saifudin (2011) dimana dalam penelitiannya menunjukkan bahwa dengan menggunakan model pembelajaran berbasis masalah dapat meningkatkan hasil belajar peserta didik dalam pembelajaran kimia.

\section{KESIMPULAN}

Berdasarkan hasil analisis data dan pembahasan hasil penelitian dapat ditarik kesimpulan sebagai berikut:

1. Keterampilan proses sains peserta didik kelas X MIA SMAN 2 Mawasangka Tengah pada materi pokok momentum dan impuls melalui penggunaan model pembelajaran berbasis masalah berbasis cenderung mengalami peningkatan dan membaik di setiap siklus, dimana pada siklus I diperoleh skor rata-rata sebesar 1,67 yang berada pada kategori cukup sedangkan pada siklus II diperoleh skor rata-rata sebesar 2,875 yang berada pada ka tegori baik.

2. Hasil belajar fisika ranah kognitif peserta didik kelas X SMAN 2 Mawasangka Tengah yang diajar menggunakan model pembelajaran berbasis masalah diperoleh rentang nilai sebagai berikut: pada siklus I diperoleh nilai dari 51 sampai 98 dengan rata-rata 71,2 sedangkan pada siklus II diperoleh nilai dari 64 sampai 100 dengan rata-rata 81,1 .

3. Ketuntasan hasil belajar fisika ranah kognitif peserta didik kelas X SMAN 2 Mawasangka Tengah pada materi pokok momentun dan impuls dapat ditingkatkan dengan menerapkan model pembelajaran berbasis masalah, hal ini ditunjukkan dengan perolehan nilai rata-rata hasil belajar pada siklus I sebesar 71,2 dengan persentase yang sudah tuntas sebesar 60,8\% sedangkan pada siklus II rata-rata hasil belajar siswa meningkat menjadi 81,1 dengan persentase yang sudah tuntas sebesar $78,3 \%$.

\section{DAFTAR PUSTAKA}

Amala, Faristin. (2012). Implementasi Model Pembelajaran Berbasis Masalah (Problem Based Learning) dalam Meningkatkan Kemampuan Berpikir Kritis pada Kompetensi Dasar Menerima dan Menyampaikan Informasi Bagi Siswa Kelas X Administrasi Perkantoran di SMK Cut Nya' Dien Semarang. Semarang: Universitas Negeri Semarang.

Arikunto, S. (2002). Dasar-dasar Evaluasi Pendidikan. Rineka Citra. Jakarta.

Hamdayama, J. (2016). Metodologi Pembelajaran. Jakarta: Bumi Aksara

Maretnowati, D. (2007). Peningkatan Hasil Belajar Fisika Pokok Materi pemuaian MelaluiPendekatan Problem Based Masalah (PBM) dengan Menggunakan Kartu Masalah di Kelas VII Semester 1 SMPN I KarangPandan Tahun Pelajaran 2006/2007. Skripsi: Tidak diterbitkan.

Mayers, B.E., Washburn, S.G \& Dyer, J.E. (2004). Assesing Agriculture Teacher' Capacity for Teaching Science Integrated Process Skills. Journal of Southern Agricultural Education Research, 54 (1), 7484.

Mulyasa. (2006). Menjadi Guru Profesional Menciptakan Pembelajaran Kreatif dan 
Menyenangkan. Bandung: Penerbit PT Remaja Rosdakarya.

Prima, E.C., \& Kurniawati, I. (2011). Penerapan Model Pembelajaran Problem Based Learning dengan Pendekatan Inkuiri Untuk Meningkatkan Keterampilan Proses Sains Dan Penguasaan Konsep Elastisitas Pada Siswa SMA. Jurnal Pendidikan MIPA, 16 (1). 179-184.

Shofa, A. (2008). Peningkatan Kreativitas Dan Hasil Belajar Fisika Melalui Pendekatan Keterampilan Proses Pada Siswa Kelas XI IPA I SMA Negeri 12 Semarang Tahun Ajaran 2007/2008. Skripsi: Tidak diterbitkan.

Wahyudi, A., Marjono, \& Harlita. (2015). Pengaruh Problem Based Learning Terhadap Keterampilan Proses Sains dan Hasil Belajar Biologi Siswa Kelas X SMA Negeri Jumapolo Tahun Pelajaran 2013/2014. Jurnal Bio-Pedagogi. 4 (1). 511.

Warsono dan Haryanto. (2012). Pembelajaran Aktif teori dan Asesmen. Bandung: Remaja Rosda Karya. 